are they listed separately, nor are they in any way distinguishable as new in the index.

Another disadvantage is that the authors set up their own rules of nomenclature, for example, adopting Fries's "Epicrisis", 1836-38, as the starting point for generic names instead of the "Systema Mycologicum", 1821-32, in accordance with the International Code of Botanical Nomenclature 1952. Lesser criticisms include unsatisfactory citation of literature and the variable spore magnifications, some being $\times 1,000$, others $\times 2,000$.

In spite of these drawbacks, the flora will be much consulted by students of special groups as well as by any amateurs who can gain access to a copy. The cost of the volume will make it well-nigh prohibitive even to many research institutes. Pilat's "Agaricales : Agaricalium Europaeorum clavis dichotomica" 1951 (unfortunately in the Czech language), with which it has much in common, includes 240 pages of photographs yet costs only $£ 511 s$., bound, compared with nearly $£ 8$, at the present rate of exchange, for the unbound French flora.

The publishers are to be congratulated on the excellent format and type. F. L. BALFOUR-BrownE

\section{ECONOMIC ORGANIZATION FOR WAR}

The Control of Raw Materials

By J. Hurstfield. (History of the Second World War : United Kingdom Civil Series.) Pp. $x v+530$. (London: H.M. Stationery Office, and Longmans, Green and Co., Ltd., 1953.) 35s. net.

TWENTIETH-CENTURY war economies are necessarily planned economies, that is, economies in which all major economic decisions are made by governments and carried out by agencies of the State. In war the conditions required by a freely operating price system to secure the production and distribution of commodities and services cease to exist, and therefore the price mechanism must be supplemented by an elaborate system of controls over every aspect of economic life. The volumes in the "United Kingdom Civil Series" on the "History of the Second World War" are adding greatly to knowledge of the economic problems of administration in war, and Mr. J. Hurstfield's study of the control of raw materials is a very important addition to the series.

The task which confronts the historian of wartime raw material controls is a formidable one. Many hundreds of raw materials ultimately came under some form of government control. Mr. Hurstfield has not, however, attempted to write the history of individual controls but has wisely preferred to review the essential features of war-time policy as it affected raw material requirements, supply and allocation, and to illustrate the development of particular aspects of policy by the experience of the more important controls of raw materials such as iron and steel, timber, wool, cotton, flax and rubber.

The volume is divided into four parts, and contains a series of excellent appendixes giving many of the data upon which Mr. Hurstfield's conclusions have been based. Part 1 deals with the pre-war preparations for the supply of raw materials in war. In this section Mr. Hurstfield reviews the relevant economic history of the inter-war years, discusses the steps initiated by the Committee of Imperial Defence "to co-ordinate the war supply arrangements of the Defence Services" and gives an excellent account of the establishment of the machinery of control, the selection of controllers drawn from the trades of which they had experience, and the controversy over the creation of the Ministry of Supply. The conclusion which Mr. Hurstfield reaches is that, although important preparatory work was carried out, "it proved impossible fully to prepare for total war without experiencing total war". The assumption of pre-war planning arrangements tended to be that "the.war would be a war of limited liability and many aspects of economic life had reasonable hopes of surviving intact". The fallacy of this assumption was made plain by events.

Part 2 is concerned first with the difficulties of definition, estimation and administration which beset the war-time planners, and secondly with the detailed estimates of requirements of specific sections of the economy, particularly with those for the Armed Services, the export trade and the civil population. Without doubt the most interesting and crucial of the topics considered in this section of the study is the development of the system of allocation in place of the so-called system of priorities. Experience proved that allocations made possible more consistency in planning than was possible by the issue of priority certificates. The allocation versus priority controversy came to a head in the summer of 1940 in the struggle between the Ministry of Supply and the Ministry of Aircraft Production over the availability of alloy steel and drop forgings. "The battle between the two Ministries," says Mr. Hurstfield, "was fought out at the Materials Committee and in the Cabinet, and unofficially in the production offices of private firms."

Part 3 examines with a wealth of detail the economic and financial problems which arose in maintaining the flow of imported raw materials under the changing fortunes of war. The vulnerability of the United Kingdom in war arises largely from her dependence upon imports of food for her human and animal populations and upon a wide range of imported raw materials for her industries. A continuous flow of supplies was essential for her survival. Mr. Hurstfield therefore discusses the changes in import policy and programmes made necessary by changes in the war situation. He has also much of interest to say about a whole series of related topics, including Anglo-American and AngloFrench relations, the replacement of imported materials by home production, the use of substitutes and the conservation of supplies, the growth of State purchasing and the difficult subject of wartime price policy for raw materials.

Finally, in Part 4, Mr. Hurstfield returns to the question of the staffing of the raw materials controls and concludes with an account of the machinery for controlling the controllers of the controls. On the first of these issues it cannot be denied that "the Second. World War was fought on the basis of employing to the maximum the ordinary channels of trade". On this controversial subject Mr. Hurstfield is non-committal. He might, however, easily have concluded that any "potential disadvantages" from employing officers drawn from the trades to staff the controls was entirely outweighed by the experience, competence, enthusiasm and unwavering loyalty of the men who were in no small messure responsible for the equipment of the British Armed Forees on land, sea and air in every quarter of the world.
E. D. MoCallum 